Research Article

\title{
COVID-19 and Cancer: Discovery of Difference in Clinical Immune Indexes
}

\author{
Xiaojiao Zeng, Xianghu Jiang, Liu Yang, Yunbao Pan $(D$, and Yirong Li \\ Department of Laboratory Medicine, Zhongnan Hospital of Wuhan University, Wuhan University, Wuhan, China \\ Correspondence should be addressed to Yunbao Pan; panyunbao@outlook.com and Yirong Li; liyirong2021@126.com
}

Received 3 July 2021; Revised 19 August 2021; Accepted 8 September 2021; Published 18 October 2021

Academic Editor: Margarete D. Bagatini

Copyright ( 2021 Xiaojiao Zeng et al. This is an open access article distributed under the Creative Commons Attribution License, which permits unrestricted use, distribution, and reproduction in any medium, provided the original work is properly cited.

\begin{abstract}
Objective. This study explored the consistency and differences in the immune cells and cytokines between patients with COVID-19 or cancer. We further analyzed the correlations between the acute inflammation and cancer-related immune disorder. Methods. This retrospective study involved 167 COVID-19 patients and 218 cancer patients. COVID-19 and cancer were each further divided into two subgroups. Quantitative and qualitative variables were measured by one-way ANOVA and chi-square test, respectively. Herein, we carried out a correlation analysis between immune cells and cytokines and used receiver operating characteristic (ROC) curves to discover the optimal diagnostic index. Results. COVID-19 and cancers were associated with lymphopenia and high levels of monocytes, neutrophils, IL-6, and IL-10. IL-2 was the optimal indicator to differentiate the two diseases. Compared with respiratory cancer patients, COVID-19 patients had lower levels of IL-2 and higher levels of $\mathrm{CD}^{+} \mathrm{CD}^{+} \mathrm{T}$ cells and $\mathrm{CD} 19^{+} \mathrm{B}$ cells. In the subgroup analysis, IL-6 was the optimal differential diagnostic parameter that had the ability to identify if COVID-19 patients would be severely affected, and severe COVID-19 patients had lower levels of lymphocyte subsets $\left(\mathrm{CD}^{+} \mathrm{T}\right.$ cells, $\mathrm{CD}^{+} \mathrm{CD}^{+} \mathrm{T}$ cells, $\mathrm{CD} 3^{+} \mathrm{CD} 8^{+} \mathrm{T}$ cells, and $\mathrm{CD} 19^{+} \mathrm{B}$ cells) and $\mathrm{CD} 16^{+} \mathrm{CD} 56^{+} \mathrm{NK}$ cells and higher level of neutrophils. There were significant differences in the levels of $\mathrm{CD}^{+} \mathrm{CD} 4^{+} \mathrm{T}$ cells and $\mathrm{CD} 19^{+} \mathrm{B}$ cells between $\mathrm{T}_{1-2}$ and $\mathrm{T}_{3-4}$ stages as well as IL-2 and CD19 ${ }^{+} \mathrm{B}$ cells between $\mathrm{N}_{0-1}$ and $\mathrm{N}_{2-3}$ stages while no significant differences between the metastatic and nonmetastatic cancer patients. Additionally, there were higher correlations between IL-2 and IL-4, TNF- $\alpha$ and IL-2, TNF- $\alpha$ and IL- 4 , TNF- $\alpha$ and IFN- $\gamma$, and CD $16^{+}$CD $56^{+}$NK cells and various subsets of T cells in COVID-19 patients. There was a higher correlation between $\mathrm{CD}^{+} \mathrm{CD} 4^{+} \mathrm{T}$ cells and $\mathrm{CD} 19^{+} \mathrm{B}$ cells in cancer patients. Conclusion. Inflammation associated with COVID-19 or cancer had effects on patients' outcomes. Accompanied by changes in immune cells and cytokines, there were consistencies, differences, and satisfactory correlations between patients with COVID-19 and those with cancers.
\end{abstract}

\section{Introduction}

A new coronavirus appeared in 2019 after two major infectious disease pandemics caused by the severe acute respiratory syndrome coronavirus (SARS-CoV) and the Middle East respiratory syndrome coronavirus (MERS-CoV) in 2002 and 2012, respectively. The virus was named SARSCoV-2 by the Coronaviridae Study Group (CSG) of the International Committee on Taxonomy of Viruses [1]. Coronavirus disease 2019 (COVID-19) caused by SARSCoV-2 has a wider and deeper impact and has been declared a Public Health Emergency of International Concern (PHEIC) by the World Health Organization (WHO). There were more than 50 million confirmed cases and more than 1 million deaths by November 2020, and the virus remains a threat to human health [2]. After SARS-CoV-2 infection, the body activates innate and adaptive immunity to implement an immune response, which results in distinct heterogeneity of COVID-19 by involving a series of physiological and pathological mechanisms, such as mild respiratory symptoms and severe respiratory diseases. Acute inflammation is critical for the regulation of tissue repair, regeneration, and homeostasis. In patients with severe COVID-19, activated immune cells produce various cytokines, and then, cytokines act on immune cells and create an amplified inflammatory cascade. Lung injury and death are mainly 
induced by an excessive inflammatory response [3]. Lymphocyte and macrophage infiltration into the lung parenchyma often occurs in COVID-19 patients [4].

Cancer, the enemy of mankind, is always harmful to human health. The incidence and mortality of cancer are rapidly increasing around the world. According to the GLOBOCAN 2020 report by the International Agency for Research on Cancer, it was estimated that there were approximately 19.3 million new cancer cases and nearly 10 million cancer deaths worldwide in 2020 [5]. In past decades, there was interest in studying the immuneinflammatory response that occurs in cancer. Infectious (Helicobacter pylori, human papillomavirus, and hepatitis B virus) and noninfectious stimulation (obesity, smoking, and alcohol consumption) can lead to the proliferation and activation of immune cells and cytokines and the formation of an inflammatory microenvironment. The stimulation of chronic inflammation easily promotes the occurrence, progression, and metastasis of cancer and cancer-related immune disorder persists and forms the tumor microenvironment [6-8].

Numerous studies have shown that there are significant changes in immune cells and cytokines during the occurrence and development of COVID-19 and cancer. Tan and Yang [9] revealed that SARS-CoV-2 can activate various immune cells ( $\mathrm{T}$ cells, B cells, macrophages, and natural killer (NK) cells) and cytokines (interleukin- (IL-) 2, IL-4, IL-6, interferon- (IFN-) $\gamma$, and tumor necrosis factor(TNF-) $\alpha$ ), which can lead to excessive inflammation and pulmonary immunopathology. Dranoff's study in 2004 found that there were complex immune cells and cytokines in the tumor microenvironment, and the interaction between them played a decisive role in the antitumor immune response [10].

In this study, we analyzed the immune cells and cytokines between COVID-19 and cancer patients to explore the consistency, difference, and differential diagnostic efficiency of these indexes between the acute inflammation and cancer-related immune disorder. In addition, COVID19 and cancer patients were each divided into two groups according to the condition of severity and metastasis. We analyzed the immune cells and cytokines of the four subgroups to discover the correlations, influencing factors, and the optimal diagnostic indexes among COVID-19 and cancer patients.

\section{Materials and Methods}

2.1. Patients. We retrospectively recruited 167 and 218 patients who were diagnosed with COVID-19 or cancer at the Zhongnan Hospital of Wuhan University from December 2018 to October 2020, respectively. There were 86 male and 81 female patients with COVID-19, with a median age of 58 (range 17-93 years). According to the clinical classification standard of the 7th edition of Guidelines for the Diagnosis and Treatment of COVID-19, those with severe or critical disease were classified as the severe group, while mild and ordinary types were classified as nonsevere groups. There were 51 severe and 116 nonsevere patients. There were 152 males and 66 females with a median age of 57 (range 9-85 years) who had respiratory and nonrespiratory cancers. There were 96 nonmetastatic and 29 metastatic cancer patients, and the status of 93 cancer patients was unknown.

2.2. Inclusion Criteria and Enrollment. The inclusion criteria in this study were (1) patients with definite diagnosis of COVID-19 and solid cancers and (2) patients with complete records of immune cells and cytokines. Exclusion criteria were as follows: (1) patients with both COVID-19 and cancers, (2) patients with hematological malignancy, and (3) patients with incomplete medical records.

2.3. Physical Examination and Hematological Data. Peripheral blood cells, such as neutrophils, lymphocytes, and monocytes, were analyzed with a Beckman Coulter DxH 800 automated blood analyzer according to the manufacturer's instructions (Beckman, California, USA). Serum cytokines, including IL-2, IL-4, IL-6, IL-10, TNF- $\alpha$, and IFN- $\gamma$, were analyzed by BD FACSCalibur flow cytometry according to the manufacturer's instructions. Peripheral absolute cell counts of $\mathrm{CD}^{+} \mathrm{T}$ cells, $\mathrm{CD}^{+} \mathrm{CD}^{+} \mathrm{T}$ cells, $\mathrm{CD}^{+}{ }^{+} \mathrm{CD} 8^{+} \mathrm{T}$ cells, $\mathrm{CD} 19^{+} \mathrm{B}$ cells, and $\mathrm{CD} 16^{+} \mathrm{CD} 56^{+}$natural killer (NK) cells were obtained by flow cytometry according to the manufacturer's instructions.

2.4. Statistical Analysis. The statistical analyses were conducted by IBM SPSS version 22.0 software (SPSS, Chicago, IL). Quantitative and qualitative variables were measured by one-way ANOVA and chi-square test, respectively. Pairwise comparisons and correlation analyses between groups were plotted by GraphPad Prism v7.0 software. The receiver operating characteristic (ROC) curve was applied to assess the diagnostic efficiency of various immune indicators. A $p$ value $<0.05$ was considered statistically significant.

\section{Results}

3.1. Baseline Characteristics between COVID-19 and Cancer Patients. The patients recruited in our study consisted of those with COVID-19 or cancer of various types. The general parameters of the patients were shown in Table 1. Cancer was common in men and younger patients, with respiratory cancers being the most common. There were significant differences between metastatic and nonmetastatic cancer patients as well as between severe and nonsevere COVID-19 patients. Moreover, most cytokines and immune cells were significantly different, including IL-6, IL-10, $\mathrm{CD}^{+}$ $\mathrm{T}$ cells, $\mathrm{CD}^{+} \mathrm{CD}^{+} \mathrm{T}$ cells, $4 / 8$ ratio, and $\mathrm{CD} 19^{+} \mathrm{B}$ cells.

3.2. Variance Analysis of Immune Cells and Cytokines in Different Groups. COVID-19 and cancer patients were each further divided into two subgroups, for a total of four subgroups, and the logarithmic levels of immune cells and cytokines were displayed in Figure S1. There were 96 nonmetastatic and 29 metastatic cancer patients, and 116 nonsevere and 51 severe COVID-19 patients, respectively (Table 1). Immune cells and cytokines of COVID-19 and cancer patients were analyzed by one-way ANOVA 
TABle 1: Baseline parameters between COVID-19 and cancer patients.

\begin{tabular}{|c|c|c|}
\hline Variables & $n$ & $p$ \\
\hline Sex & & $\leq 0.001$ \\
\hline \multicolumn{3}{|l|}{ Cancer } \\
\hline Male & 152 & \\
\hline Female & 66 & \\
\hline \multicolumn{3}{|l|}{ COVID-19 } \\
\hline Male & 86 & \\
\hline Female & 81 & \\
\hline Age & & 0.646 \\
\hline \multicolumn{3}{|l|}{ Cancer } \\
\hline$<60$ & 120 & \\
\hline$\geq 60$ & 98 & \\
\hline \multicolumn{3}{|l|}{ COVID-19 } \\
\hline$<60$ & 88 & \\
\hline$\geq 60$ & 79 & \\
\hline COVID-19 & & $\leq 0.001$ \\
\hline Nonsevere & 116 & \\
\hline Severe & 51 & \\
\hline Cancer type & & 0.104 \\
\hline Respiratory system & 121 & \\
\hline Nonrespiratory system & 97 & \\
\hline Cancer distant metastasis & & $\leq 0.001$ \\
\hline M0 & 96 & \\
\hline M1 & 29 & \\
\hline Unknown & 93 & \\
\hline IL-2 & & 0.906 \\
\hline \multicolumn{3}{|l|}{ Cancer } \\
\hline Normal & 195 & \\
\hline High & 23 & \\
\hline \multicolumn{3}{|l|}{ COVID-19 } \\
\hline Normal & 150 & \\
\hline High & 17 & \\
\hline IL-4 & & 0.156 \\
\hline \multicolumn{3}{|l|}{ Cancer } \\
\hline Normal & 198 & \\
\hline High & 20 & \\
\hline \multicolumn{3}{|l|}{ COVID-19 } \\
\hline Normal & 144 & \\
\hline High & 23 & \\
\hline IL-6 & & $\leq 0.001$ \\
\hline \multicolumn{3}{|l|}{ Cancer } \\
\hline Normal & 48 & \\
\hline High & 170 & \\
\hline \multicolumn{3}{|l|}{ COVID-19 } \\
\hline Normal & 83 & \\
\hline High & 84 & \\
\hline IL-10 & & $\leq 0.001$ \\
\hline
\end{tabular}

TABle 1: Continued.

\begin{tabular}{|c|c|c|}
\hline Variables & $n$ & $p$ \\
\hline \multicolumn{3}{|l|}{ Cancer } \\
\hline Normal & 188 & \\
\hline High & 30 & \\
\hline \multicolumn{3}{|l|}{ COVID-19 } \\
\hline Normal & 118 & \\
\hline High & 49 & \\
\hline IFN- $\gamma$ & & 0.105 \\
\hline \multicolumn{3}{|l|}{ Cancer } \\
\hline Normal & 218 & \\
\hline High & 0 & \\
\hline \multicolumn{3}{|l|}{ COVID-19 } \\
\hline Normal & 165 & \\
\hline High & 2 & \\
\hline TNF- $\alpha$ & & 0.850 \\
\hline \multicolumn{3}{|l|}{ Cancer } \\
\hline Normal & 217 & \\
\hline High & 1 & \\
\hline \multicolumn{3}{|l|}{ COVID-19 } \\
\hline Normal & 166 & \\
\hline High & 1 & \\
\hline $\mathrm{CD}^{+}{ }^{+} \mathrm{Abs} \mathrm{Cnt}$ & & 0.028 \\
\hline \multicolumn{3}{|l|}{ Cancer } \\
\hline Normal & 102 & \\
\hline Low & 116 & \\
\hline \multicolumn{3}{|l|}{ COVID-19 } \\
\hline Normal & 97 & \\
\hline Low & 70 & \\
\hline $\mathrm{CD}^{+} \mathrm{CD}^{+} \mathrm{Abs} \mathrm{Cnt}$ & & 0.003 \\
\hline \multicolumn{3}{|l|}{ Cancer } \\
\hline Normal & 126 & \\
\hline Low & 92 & \\
\hline \multicolumn{3}{|l|}{ COVID-19 } \\
\hline Normal & 121 & \\
\hline Low & 46 & \\
\hline $\mathrm{CD}^{+} \mathrm{CD}^{+}{ }^{+}$Abs Cnt & & 0.109 \\
\hline \multicolumn{3}{|l|}{ Cancer } \\
\hline Normal & 79 & \\
\hline Low & 139 & \\
\hline \multicolumn{3}{|l|}{ COVID-19 } \\
\hline Normal & 74 & \\
\hline Low & 93 & \\
\hline $4 / 8$ ratio & & 0.014 \\
\hline \multicolumn{3}{|l|}{ Cancer } \\
\hline Normal & 110 & \\
\hline High & 56 & \\
\hline Low & 52 & \\
\hline
\end{tabular}


TABLE 1: Continued.

\begin{tabular}{|c|c|c|}
\hline Variables & $n$ & $p$ \\
\hline \multicolumn{3}{|l|}{ COVID-19 } \\
\hline Normal & 90 & \\
\hline High & 56 & \\
\hline Low & 21 & \\
\hline $\mathrm{CD} 19^{+} \mathrm{Abs} \mathrm{Cnt}$ & & 0.019 \\
\hline \multicolumn{3}{|l|}{ Cancer } \\
\hline Normal & 35 & \\
\hline Low & 183 & \\
\hline \multicolumn{3}{|l|}{ COVID-19 } \\
\hline Normal & 43 & \\
\hline Low & 124 & \\
\hline $\mathrm{CD} 16^{+} \mathrm{CD} 56^{+} \mathrm{Abs} \mathrm{Cnt}$ & & 0.403 \\
\hline \multicolumn{3}{|l|}{ Cancer } \\
\hline Normal & 102 & \\
\hline Low & 116 & \\
\hline \multicolumn{3}{|l|}{ COVID-19 } \\
\hline Normal & 71 & \\
\hline Low & 96 & \\
\hline LYM & & 0.625 \\
\hline \multicolumn{3}{|l|}{ Cancer } \\
\hline Normal & 111 & \\
\hline High & 1 & \\
\hline Low & 106 & \\
\hline \multicolumn{3}{|l|}{ COVID-19 } \\
\hline Normal & 89 & \\
\hline Low & 78 & \\
\hline NEU & & 0.260 \\
\hline \multicolumn{3}{|l|}{ Cancer } \\
\hline Normal & 144 & \\
\hline High & 53 & \\
\hline Low & 21 & \\
\hline \multicolumn{3}{|l|}{ COVID-19 } \\
\hline Normal & 122 & \\
\hline High & 35 & \\
\hline Low & 10 & \\
\hline MONO & & 0.268 \\
\hline \multicolumn{3}{|l|}{ Cancer } \\
\hline Normal & 148 & \\
\hline High & 65 & \\
\hline Low & 5 & \\
\hline \multicolumn{3}{|l|}{ COVID-19 } \\
\hline Normal & 126 & \\
\hline High & 38 & \\
\hline Low & 3 & \\
\hline
\end{tabular}

Abbreviations: M: metastasis; $\mathrm{CD}^{+} \mathrm{Abs}$ : absolute count of $\mathrm{CD}^{+} \mathrm{T}$ cells; $\mathrm{CD}^{+} \mathrm{CD}^{+}$Abs: absolute count of $\mathrm{CD}^{+} \mathrm{CD} 4^{+} \mathrm{T}$ cells; $\mathrm{CD} 3^{+} \mathrm{CD} 8^{+} \mathrm{Abs}$ : absolute count of $\mathrm{CD}^{+} \mathrm{CD}^{+} \mathrm{T}$ cells; $\mathrm{CD} 19^{+} \mathrm{Abs}$ : absolute count of $\mathrm{CD} 19^{+}$ $\mathrm{B}$ cells; $\mathrm{CD} 16^{+} \mathrm{CD} 56^{+}$Abs: absolute count of $\mathrm{CD} 16^{+} \mathrm{CD} 56^{+} \mathrm{NK}$ cells; LYM: lymphocyte; NEU: neutrophil; MONO: monocyte.
(Figure 1). The results showed that there were significant differences in the levels of IL-2, IL-10, absolute count of lymphocyte subsets $\left(\mathrm{CD}^{+}{ }^{+} \mathrm{T}\right.$ cells, $\mathrm{CD}^{+} \mathrm{CD}^{+} \mathrm{T}$ cells, $\mathrm{CD}^{+} \mathrm{CD}^{+}{ }^{+}$cells, and $\mathrm{CD} 19^{+} \mathrm{B}$ cells), $\mathrm{CD} 16^{+} \mathrm{CD} 56^{+} \mathrm{NK}$ cells, and neutrophils between patents with COVID-19 and cancers. Moreover, immune cell levels were statistically different between COVID-19 subgroups, including lymphocyte subsets, NK cells, and neutrophils, whereas there was no significant difference between metastatic and nonmetastatic cancer subgroups (Figure 1). Moreover, we further analyzed immune cells and cytokines in different $\mathrm{T}$ stages, $\mathrm{N}$ stages, and differentiation of cancers (Table S1). There were significant differences in the levels of $\mathrm{CD}^{+} \mathrm{CD}^{+}$ $T$ cells and $C D 19^{+} B$ cells between $T_{1-2}$ and $T_{3-4}$ stages as well as IL-2 and CD19 ${ }^{+} \mathrm{B}$ cells between $\mathrm{N}_{0-1}$ and $\mathrm{N}_{2-3}$ stages (Figure S2).

There were 121 patients with respiratory cancers and 97 patients with nonrespiratory cancers (Table S1). And there were significant differences in the levels of NK cells and neutrophils between squamous carcinoma and adenocarcinoma in patients with respiratory cancers as well as NK cells between patients with distant and nondistant metastatic respiratory cancers (Figure S2). A further analysis was conducted of immune cells and cytokines among patients with COVID-19 or cancer. The results suggested that there were significant differences in the levels of IL-2, IL-6, IL-10, $\mathrm{CD}^{+}{ }^{+} \mathrm{T}$ cells, $\mathrm{CD} 3^{+} \mathrm{CD} 4^{+} \mathrm{T}$ cells, and $\mathrm{CD} 19^{+} \mathrm{B}$ cells (Figure 2).

3.3. Correlation Analysis of Immune Cells and Cytokines. A correlation analysis was performed on immune cells and cytokines among patients with COVID-19 or cancer (Figure 3). The results suggested that there was a satisfactory correlation among most of these inflammatory markers, and the correlation analysis was plotted (Figure 4). In the severe COVID-19 group, the correlation coefficients between IL-4 and IL-2, CD $16^{+} \mathrm{CD}_{5} 6^{+} \mathrm{NK}$ cells and $\mathrm{CD}^{+}{ }^{+} \mathrm{T}$ cells, $\mathrm{CD} 16^{+-}$ $\mathrm{CD}^{2} 6^{+} \mathrm{NK}$ cells and $\mathrm{CD} 3^{+} \mathrm{CD} 4^{+} \mathrm{T}$ cells, $\mathrm{CD} 16^{+} \mathrm{CD} 56^{+} \mathrm{NK}$ cells and $\mathrm{CD}^{+}{ }^{+} \mathrm{CD} 8^{+} \mathrm{T}$ cells, TNF- $\alpha$ and IL-2, TNF- $\alpha$ and IL-4, and TNF- $\alpha$ and IFN- $\gamma$ were $0.961,0.804,0.659$, $0.848,0.733,0.7$, and 0.629 , respectively. In the nonsevere COVID-19 group, the correlation coefficients of IL- 4 and IL-2, TNF- $\alpha$ and IL-2, TNF- $\alpha$ and IFN- $\gamma$, and TNF- $\alpha$ and IL-4 were $0.887,0.795,0.699$, and 0.674 , respectively. In the metastatic group, the correlation coefficient between $\mathrm{IL}-4$ and IL-2, and $\mathrm{CD}^{+}{ }^{+} \mathrm{CD}_{4}{ }^{+} \mathrm{T}$ cells and $\mathrm{CD} 19^{+} \mathrm{B}$ cells were 0.848 and 0.655 , respectively. Additionally, the correlation coefficients were 0.66 and 0.598 in the nonmetastatic group for two pairs of indexes, respectively. Moreover, the correlation coefficients for IL- 4 and IL-2, IL- 4 and TNF- $\alpha$, and NK cells and T cells were the lowest in nonmetastatic patients, followed by metastatic and nonsevere COVID-19 patients, and were the highest in severe COVID-19 patients. The correlation coefficients for TNF- $\alpha$ and IL-2, and TNF- $\alpha$ and IFN- $\gamma$ were higher in the COVID-19 group than that in the cancer group, while the correlation coefficients between $\mathrm{CD}_{3}{ }^{+} \mathrm{CD} 4^{+} \mathrm{T}$ cells and $\mathrm{CD} 19^{+} \mathrm{B}$ cells were higher in the cancer group than that in the COVID-19 group (Figure 3). 

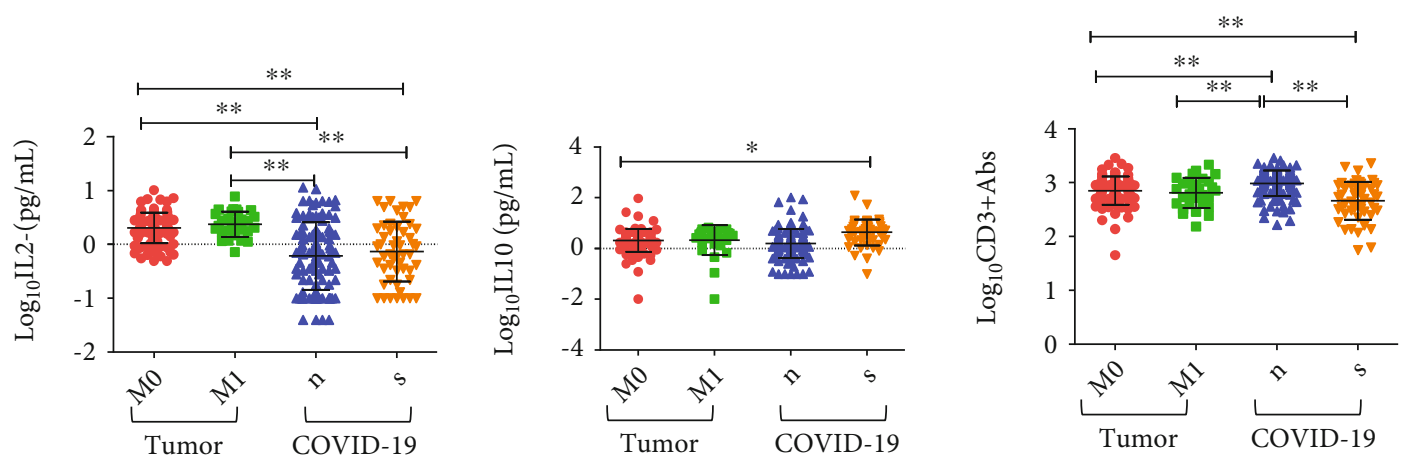

(a)
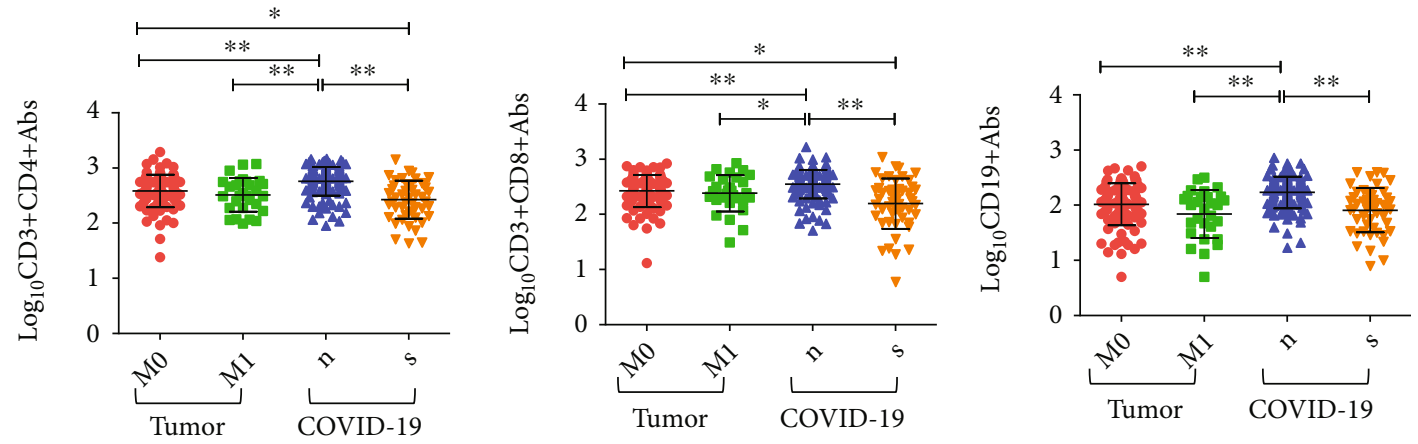

(b)
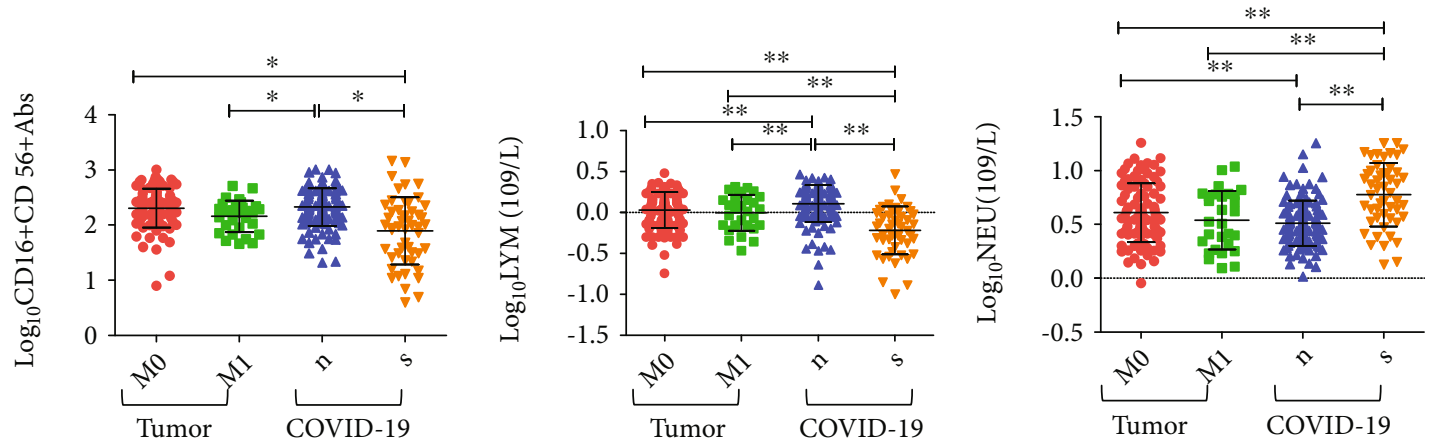

(c)

FIgURE 1: Analysis of immune cells and cytokines in the four subgroups of patients with COVID-19 or cancer. $n$ : nonsevere; $s$ : severe. (a) IL2 (left), IL-10 (middle), and $\mathrm{CD}^{+} \mathrm{Abs}$ (right). (b) $\mathrm{CD}^{+} \mathrm{CD} 4^{+} \mathrm{Abs}$ (left), $\mathrm{CD}^{+} \mathrm{CD}^{+} \mathrm{Abs}$ (middle), and $\mathrm{CD} 19^{+} \mathrm{Abs}$ (right). (c) $\mathrm{CD} 16^{+} \mathrm{CD} 56^{+} \mathrm{Abs}$ (left), LYM (middle), and NEU (right).

In addition, there was a significant correlation between immune cells and cytokines (Figure 5). Monocytes were negatively correlated with IL-2, IL-4, and TNF- $\alpha$ in the COVID-19 severe group. In the metastatic group, neutrophils were positively correlated with IL-10. In the nonmetastatic group, NK cells and lymphocytes were positively correlated with IL-2 and negatively correlated with IL-6, and T cells were positively correlated with IL- 4 and TNF- $\alpha$ and negatively correlated with IL-6 and IL-10.

3.4. ROC Curve Analysis of Immune Cells and Cytokines. We used ROC curves to explore the ability of immune cells and cytokines to differentiate between COVID-19 and cancers (Figure 6(a)). The area under the ROC curve (AUC) for IL-2 $(0.741,0.687-0.796)$ was larger than that for the other indexes, indicating that IL-2 was the most optimal differential diagnostic value between the two diseases. The AUC of the cytokines IL-4, IL- 6 , IL-10, IFN- $\gamma$, and TNF- $\alpha$ was $0.679,0.669,0.541,0.647$, and 0.553 , respectively. The AUCs of the $\mathrm{CD} 3^{+} \mathrm{CD} 4^{+} \mathrm{T}$ and $\mathrm{CD} 19^{+} \mathrm{B}$ immune cells were 0.606 and 0.61 , respectively. We further investigated the ability of immune indexes to differentiate between severe and nonsevere COVID-19 (Figure 6(b)). The AUCs of immune indexes such as IL-6, IL-10, neutrophils, $\mathrm{CD}^{+} \mathrm{T}$ cells, $\mathrm{CD}^{+}{ }^{+} \mathrm{CD} 4^{+} \mathrm{T}$ cells, $\mathrm{CD}^{+} \mathrm{CD}^{+} \mathrm{T}$ cells, $\mathrm{CD} 19^{+} \mathrm{B}$ cells, $\mathrm{CD} 16^{+} \mathrm{CD} 56^{+} \mathrm{NK}$ cells, and lymphocytes were 0.848 , $0.743,0.768,0.792,0.791,0.76,0.746,0.733$, and 0.839 , respectively. These results suggested that there was more optimal differential diagnostic value for IL-6 and lymphocytes between the two groups of COVID-19 patients. 

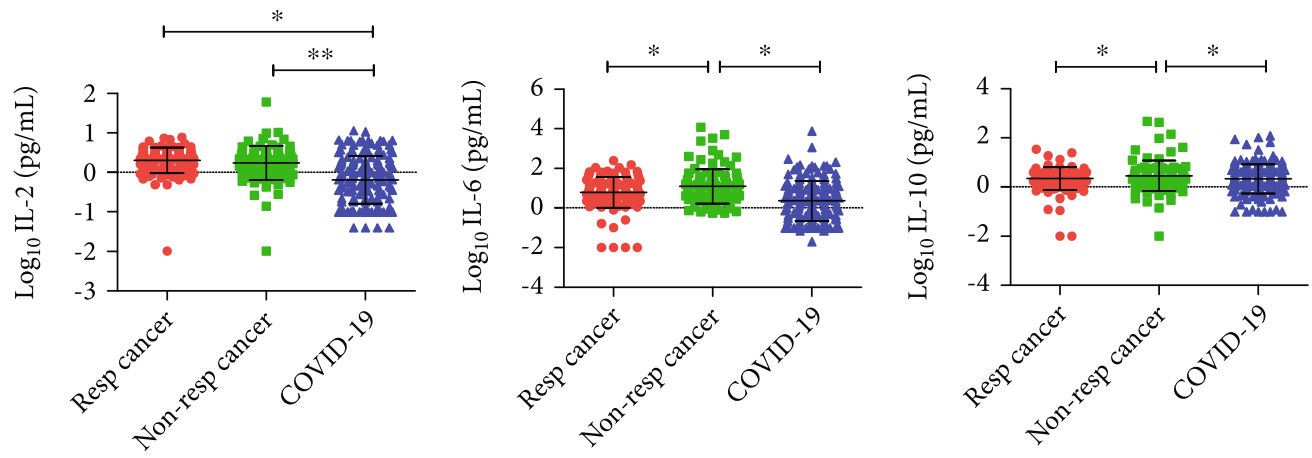

(a)
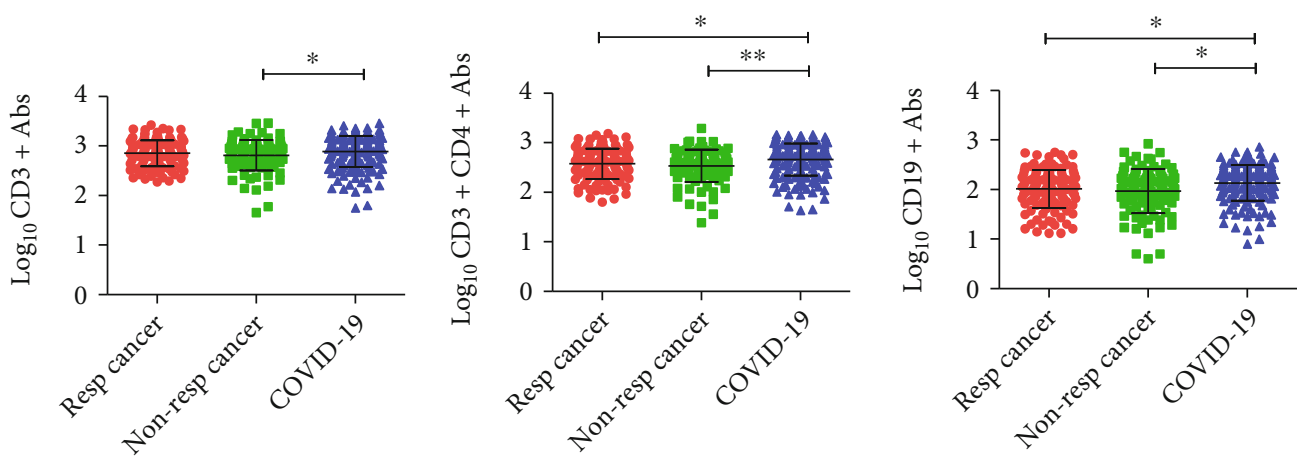

(b)

Figure 2: Analysis of immune cells and cytokines in three groups of patients with COVID-19 or cancer. Resp: respiratory cancer; Non-resp: nonrespiratory cancer. (a) IL-2 (left), IL-6 (middle), and IL-10 (right). (b) $\mathrm{CD}^{+}$Abs (left), $\mathrm{CD}^{+} \mathrm{CD}^{+} \mathrm{Abs}$ (middle), and CD19 ${ }^{+} \mathrm{Abs}$ (right).

However, they exhibited poor diagnostic efficiency in differentiating distant metastatic patients from nonmetastatic patients (Figure S3).

\section{Discussion}

Most studies have shown that COVID-19 is often accompanied by lymphopenia, and high levels of neutrophils and mononuclear macrophages in patients. Cytokine storms with significant increases in IL-6 and IL-10 often occur in patients with severe COVID-19 and may play an important role in the development of lymphopenia, high neutrophils, and high mononuclear macrophages [11-13]. Giamarellos-Bourboulis et al. [14] reported that immune dysregulation in cases of severe COVID-19 was mainly characterized by low expression of IL-6-mediated human leukocyte antigen D-related (HLADR) and a decrease in lymphocytes and NK cells. Jamilloux et al. [15] found that the type I IFN response was prolonged or decreased in COVID-19 patients, the innate and adaptive immune responses were suppressed, and both NK cells and lymphocyte subsets were reduced, which indicates that SARS-CoV-2 is not subject to immune control.

An excessive inflammatory response is significantly correlated with poor prognosis in COVID-19 patients. Moreover, $\mathrm{Li}$ et al. [16] showed that IL-2, IL-4, IFN- $\gamma$, and TNF- $\alpha$ levels were not significantly different between deceased patients and survivors of COVID-19, and the absolute counts of $\mathrm{CD}^{+} \mathrm{T}$ cells, $\mathrm{CD}^{+} \mathrm{CD}^{+} \mathrm{T}$ cells, and $\mathrm{CD}^{+-}$ $\mathrm{CD}^{+} \mathrm{T}$ cells in the deceased group were always at a low level. $\mathrm{Wu}$ et al. [17] showed that there were no significant differences in IL-6, IFN- $\gamma$, TNF- $\alpha$, or lymphocyte levels between patients with mild and moderate COVID-19, while the IL-10 level was significantly increased, and the neutrophil level was significantly decreased in the moderate group.

In this study, there were no significant differences in cytokines between the severe and nonsevere COVID-19 groups. In accordance with the conclusion of previous studies, the neutrophils were significantly elevated, and the absolute counts of $\mathrm{CD}^{+}{ }^{+} \mathrm{T}$ cells, $\mathrm{CD} 3^{+} \mathrm{CD} 4^{+} \mathrm{T}$ cells, $\mathrm{CD}^{+} \mathrm{CD}^{+}$ $\mathrm{T}$ cells, CD19 ${ }^{+} \mathrm{B}$ cells, and $\mathrm{NK}$ cells were significantly decreased in patients with severe COVID-19. Moreover, ROC curve analysis suggested that IL-6 was the optimal diagnostic index to distinguish severe and nonsevere COVID-19 in patients.

Currently, many studies have proved the relationship between chronic inflammation and the occurrence and development of cancers. Our previous studies also reported the relationship between immune cells and prognosis of cancer [18]. Neutrophils and monocytes can induce immune tolerance, distant metastasis, chemotherapy resistance, and cancer progression by forming tumor-associated neutrophils (TAN) and tumor-associated macrophages (TAM). The effective immunity of cancer mainly depends on the function of $\mathrm{NK}$ cells and $\mathrm{CD}^{+} \mathrm{CD}^{+} \mathrm{T}$ cells, as cytotoxic lymphocytes of the innate and adaptive immune system, respectively [19-21]. Toyoshima et al. [22] reported that high levels of IL-6 can interfere with type-I IFN signals in the immune system and is accompanied by low expression 


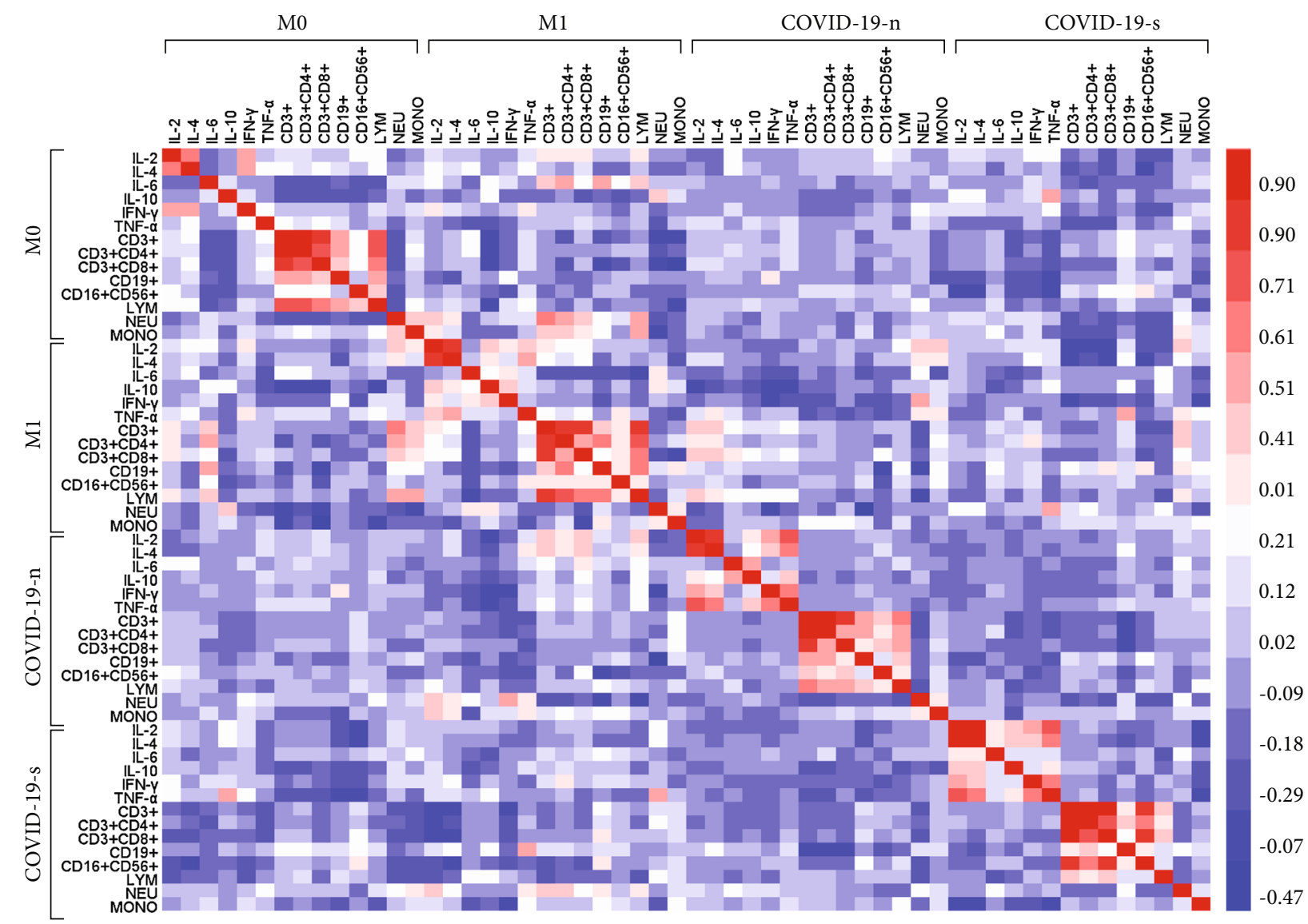

FIgURE 3: Heat maps for correlation coefficients of patients with COVID-19 or cancer. M0: nonmetastatic cancer patients; M1: metastatic cancer patients; COVID-19-n nonsevere COVID-19 patients; COVID-19-s: severe COVID-19 patients.

of major histocompatibility complex class I (MHC I) molecules, which can then weaken the antitumor effect of $\mathrm{CD}^{+-}$ $\mathrm{CD}^{+} \mathrm{T}$ cells and promote tumor growth, development, and distant colonization. IL-10, an anti-inflammatory cytokine, protects the body from damage caused by immune overreaction, while IL-10 in cancer has two opposite effects. A high level of IL-10 has an immunosuppressive effect that facilitates the immune escape of cancer cells, but IL-10 also has an antitumor effect by increasing the infiltration of $\mathrm{CD} 3+\mathrm{CD} 8+\mathrm{T}$ cells and the production of IFN- $\gamma$ in tissues, which may be related to the fact that IL-10 targets different cells (myeloid and $\mathrm{T}$ cells) in different cancers or that $\mathrm{T}$ cells respond differently to IL-10 at different effective stages [23].

These studies showed that both COVID-19 and cancer have the phenomenon of interference in the type-I IFN response, immunosuppression, and high levels of cytokines, such as IL-6 and IL-10. Our results were consistent with these conclusions. When we analyzed the immune cells and cytokines between COVID-19 and cancer patients, we discovered that there were similar changes in these biomarkers, such as low lymphocytes, high monocytes, high neutrophils, high IL-6, and high IL-10. The ROC curve suggested that IL-2 was the optimal diagnostic index for both diseases. We further compared the immune cells and cyto- kines in patients with COVID-19 or respiratory cancers. The results showed that there was no significant difference in IL- 6 and IL-10 between the two groups, while COVID19 patients had lower levels of IL-2 and higher levels of $\mathrm{CD}^{+} \mathrm{CD}^{+} \mathrm{T}$ cells and $\mathrm{CD} 19^{+} \mathrm{B}$ cells. Moreover, the interaction between cancer and inflammation is regulated through a complex network. The inflammatory response may be varied at different stages of cancer development. Our study suggested that cancer patients in $\mathrm{T}_{3-4}$ stages had lower levels of $\mathrm{CD}^{+} \mathrm{CD}^{+} \mathrm{T}$ cells and $\mathrm{CD} 19^{+} \mathrm{B}$ cells, and patients in $\mathrm{N}_{2-3}$ stages had lower levels of $\mathrm{CD}^{+} 9^{+} \mathrm{B}$ cells and higher levels of IL-2. In addition, we conducted a correlation analysis of these inflammatory indexes in COVID-19 and cancers, and the results suggested that there was a higher correlation between IL-2 and IL-4, NK cells and T cells in COVID-19 patients, and a higher correlation between $\mathrm{CD}^{+-}$ $\mathrm{CD}^{+} \mathrm{T}$ cells and $\mathrm{CD} 19^{+} \mathrm{B}$ cells in cancer patients.

Luo et al. [24] revealed that multiple elevated cytokines were associated with poor prognosis of severe COVID-19 patients, including IL-2, IL-4, IL-6, IL-10, IFN- $\gamma$, and TNF$\alpha$. With the same cytokine receptor $\gamma$ chain, IL-2 and IL-4 together regulate cell differentiation, promote the formation of immune cells, improve the killing activity of cytotoxic $\mathrm{T}$ lymphocyte (CTL) and NK cells, and play an important role in inflammation and cancers [25]. Our study showed that 

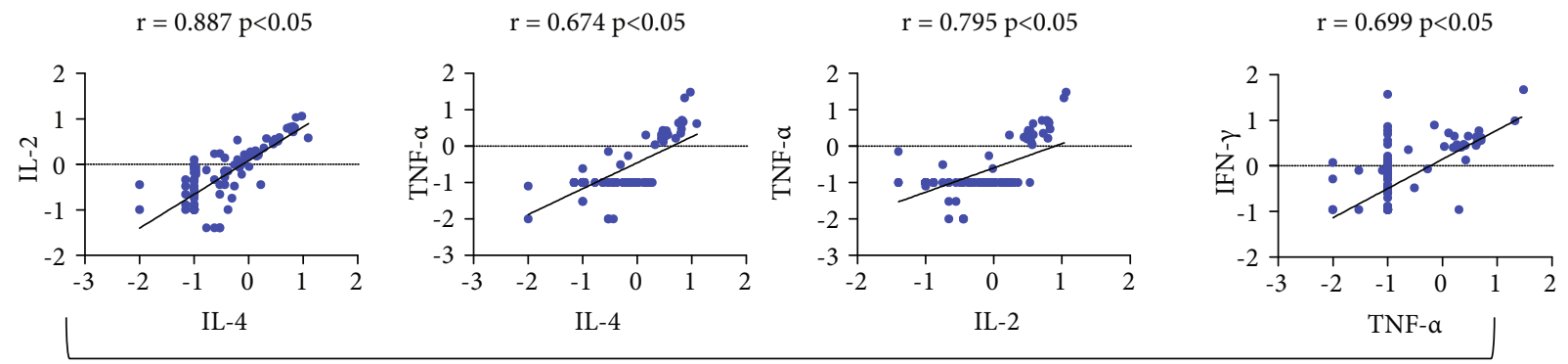

COVID-19-n

$\mathrm{r}=0.961 \mathrm{p}<0.05$

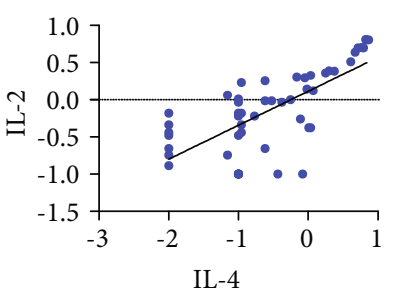

$\mathrm{r}=0.804 \mathrm{p}<0.05$

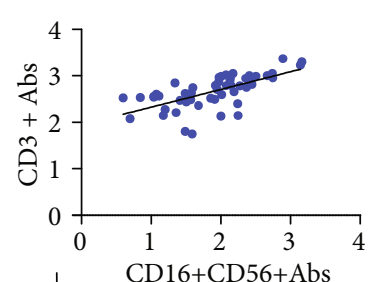

CD16+CD56+Abs

$$
\mathrm{r}=0.7 \mathrm{p}<0.05
$$

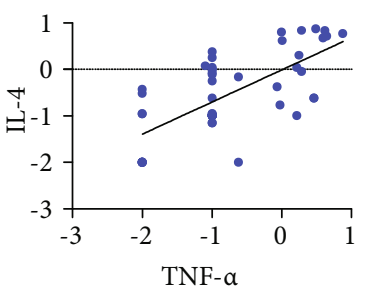

$r=0.659 p<0.05$

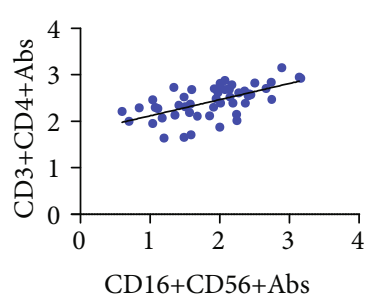

$\mathrm{r}=0.733 \mathrm{p}<0.05$

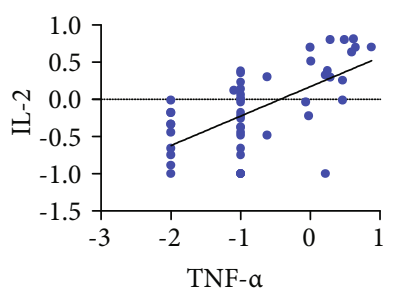

$=0.848 \mathrm{p}<0.05$

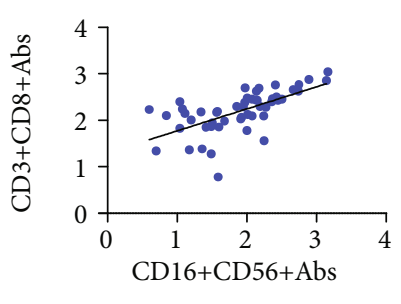

(a)

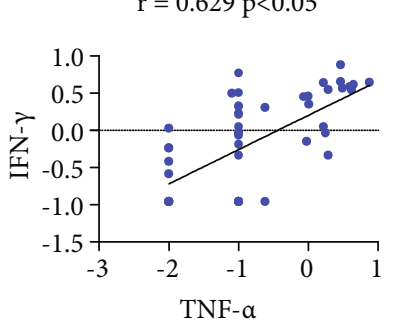

COVID-19-s
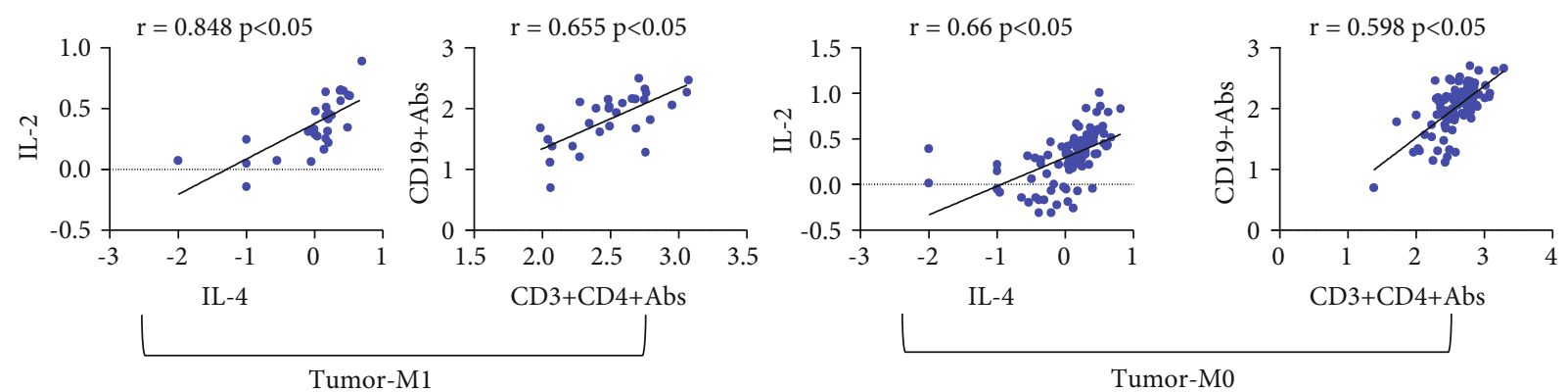

$\mathrm{CD} 3+\mathrm{CD} 4+\mathrm{Abs}$

Tumor-M0

(b)

FIgURE 4: The correlation analysis of the four subgroups of patients with COVID-19 or cancer. (a) COVID-19 patients. (b) Cancer patients.

there was a good correlation between IL-2 and IL-4 in patients with COVID-19 or cancers.

TNF- $\alpha$ can guide circulating monocytes to the site of injury so that they can differentiate into mature macrophages [6]. Cytokines secreted by macrophages can activate NK cells, and IFN- $\gamma$ produced by NK cells acts on alveolar macrophages to amplify the inflammatory response [26]. Karki et al. [27] reported that the synergistic effects of TNF- $\alpha$ and IFN- $\gamma$ in COVID-19 patients can induce various types of cell death and tissue damage and result in a poor prognosis. In patients with severe COVID-19, we found that TNF- $\alpha$ was satisfactorily correlated with IL-2, IL-4, and
IFN- $\gamma$, and monocytes were negatively correlated with IL2 , IL-4, and TNF- $\alpha$. In nonmetastatic cancer patients, T cells were negatively correlated with IL- 6 and IL-10 and were positively correlated with IL- 4 and TNF- $\alpha$.

Although we conducted an analysis of different immune cells and cytokines between COVID-19 and cancers, there were some deficiencies in our study. The examination of cytokines was carried out in 2018, and there was incomplete case information for many cancer patients. Thus, only 29 metastatic patients were recruited, and they were accompanied by 93 cases with unknown metastatic status in this study. In addition, this was a single-center retrospective 

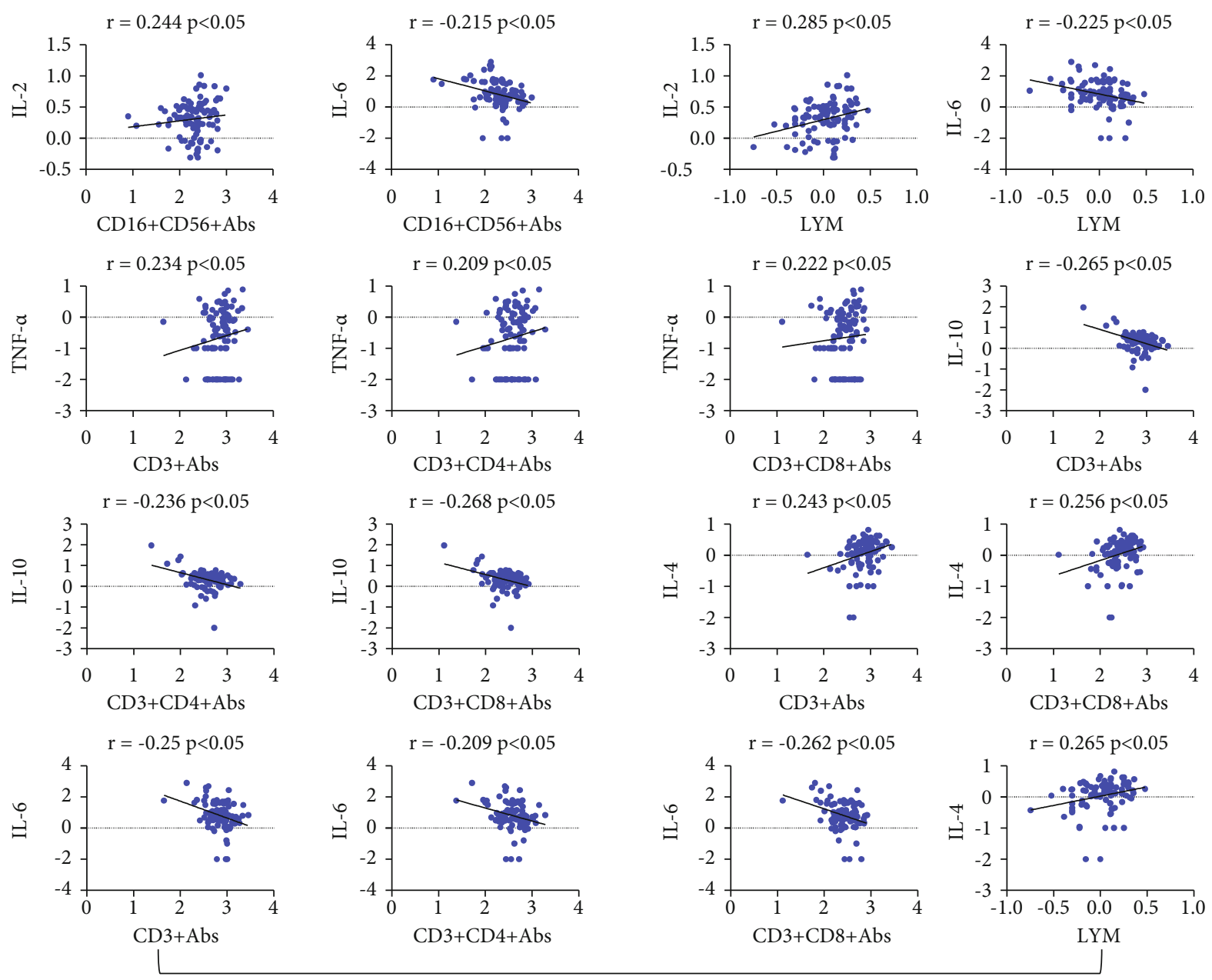

Tumor-M0

(a)
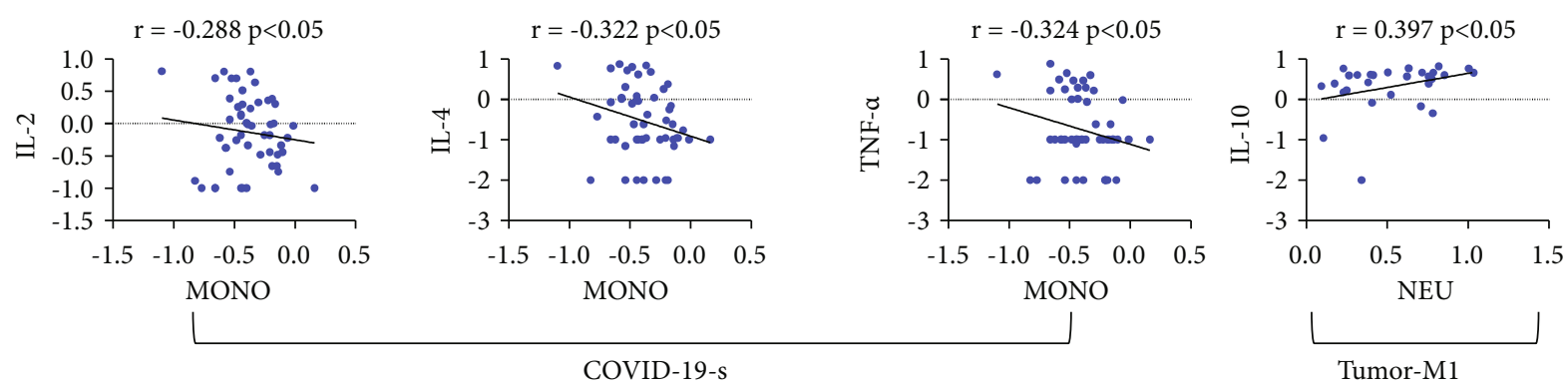

(b)

(c)

FIGURE 5: The correlation analysis between immune cells and cytokines of patients with COVID-19 or cancer. (a) Nonmetastatic cancer patients. (b) Severe COVID-19 patients. (c) Metastatic cancer patients.

study. We require data from a larger and multicenter cohort to better assess the changes in immune response after acute infection and cancer-related immune disorder.

In conclusion, both COVID-19 and cancers were associated with lymphopenia and high levels of monocytes, neutrophils, IL-6, and IL-10. IL-2 was the optimal indicator to differentiate between the COVID-19 and cancerrelated immune disorder. In comparing patients with respiratory cancers, COVID-19 patients had lower levels of IL-2 and higher levels of $\mathrm{CD}^{+} \mathrm{CD}^{+} \mathrm{T}$ cells and $\mathrm{CD} 19^{+} \mathrm{B}$ cells, and no difference in levels of IL- 6 and IL-10. In addition, there were higher correlations between IL- 2 and IL- 4 , TNF- $\alpha$ and IL-2, TNF- $\alpha$ and IL- 4 , TNF- $\alpha$ and IFN- $\gamma$, and NK cells and T cells in COVID-19 patients, and there was a higher correlation between $\mathrm{CD}^{+}{ }^{+} \mathrm{CD} 4^{+} \mathrm{T}$ cells and $\mathrm{CD} 19+\mathrm{T}$ cells in cancer patients. 

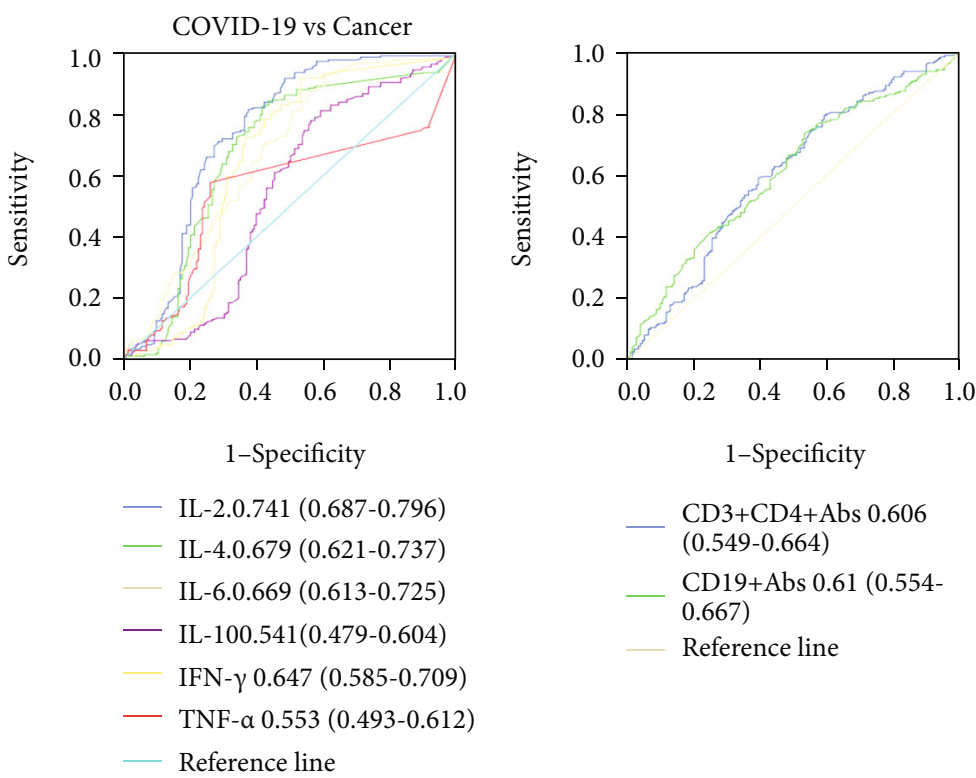

CD3+CD4+Abs 0.606 (0.549-0.664) CD19+Abs 0.61 (0.5540.667)

Reference line

(a)

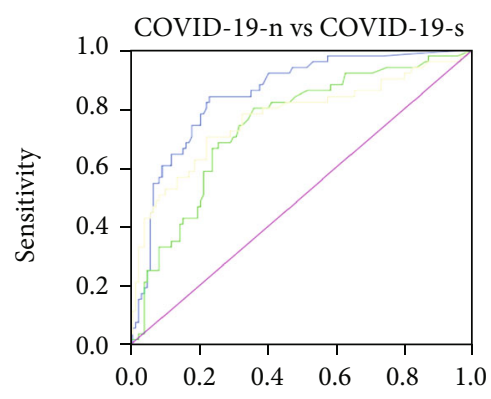

1-Specificity

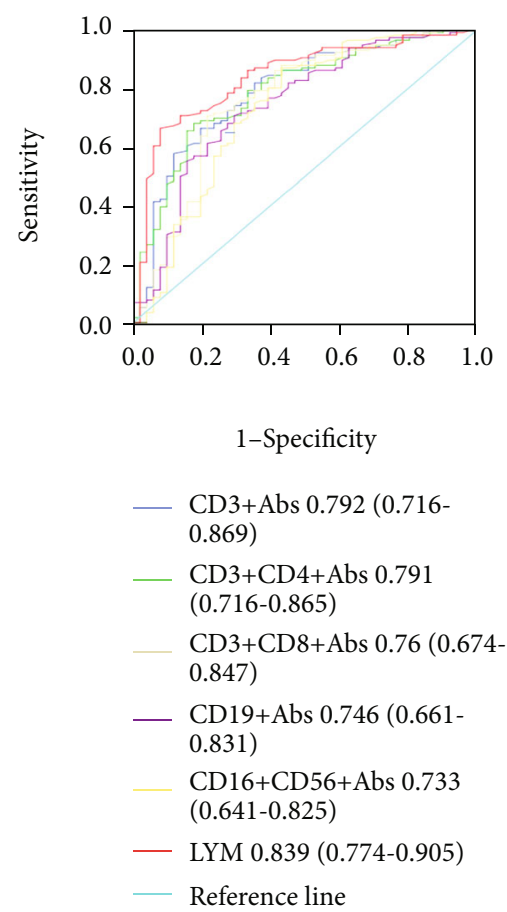

(b)

Figure 6: ROC curve analysis of immune cells and cytokines. (a) Between COVID-19 and cancer patients and (b) between severe and nonsevere COVID-19 patients.

Moreover, there were lower levels of lymphocyte subsets $\left(\mathrm{CD}^{+}{ }^{+} \mathrm{T}\right.$ cells, $\mathrm{CD}^{+}{ }^{+} \mathrm{CD} 4^{+} \mathrm{T}$ cells, $\mathrm{CD}^{+} \mathrm{CD}^{+} \mathrm{T}$ cells, and $\mathrm{CD} 19^{+} \mathrm{B}$ cells) and NK cells and higher level of neutrophils in severe COVID-19 patients, and IL-6 exhibited the most optimal ability for differential diagnosis between severe and nonsevere COVID-19 patients. As for cancer patients, there were no significant differences in immune cells and cytokines between the metastatic and the nonmetastatic group.

\section{Data Availability}

The original contributions presented in the study are included in the article material. Further inquiries can be directed to the corresponding authors.

\section{Conflicts of Interest}

The authors declare that they have no conflicts of interest. 


\section{Authors' Contributions}

Conceptualization was done by YP. Methodology was done by $\mathrm{XZ}$ and $\mathrm{XJ}$. Formal analysis was done by $\mathrm{XZ}$ and $\mathrm{LY}$. Investigation was done by $\mathrm{YP}$ and YL. Writing-original draft was done by XZ. Writing-review and editing was done by YP. Supervision was done by YP and YL. Xiaojiao Zeng and Xianghu Jiang contributed equally to this work and should be considered as co-first authors.

\section{Acknowledgments}

This work was supported by the National Natural Science Foundation of China (81872200, 31900558), the National Key Research and Development Program of China (2018YFE0204500), and the Zhongnan Hospital of Wuhan University Science, Technology and Innovation Seed Fund (ZNPY2019002).

\section{Supplementary Materials}

Supplementary 1. Figure S1: heat maps for levels of various immune cells and cytokines in patients with COVID-19 or cancer.

Supplementary 2. Figure S2: analysis of immune cells and cytokines in different stages and differentiations of cancers. (a) Between $\mathrm{T}_{1-2}$ and $\mathrm{T}_{3-4}$ and (b) between $\mathrm{N}_{0-1}$ and $\mathrm{N}_{2-3}$ and (c) between squamous carcinoma and adenocarcinoma of respiratory cancers and (d) between M0 and M1 of respiratory and nonrespiratory cancers. (a) $\mathrm{CD}^{+} \mathrm{CD}^{+} \mathrm{Abs}$ (left), $\mathrm{CD} 19^{+}$Abs (middle), LYM (right). (b) IL-2 (left), CD19 ${ }^{+}$ Abs (right). (c) $\mathrm{CD} 16^{+} \mathrm{CD} 56^{+} \mathrm{Abs}$ (left), $\mathrm{NEU}$ (right). (d) IL-6 (left), TNF- $\alpha$ (middle), CD $16^{+} \mathrm{CD} 56^{+}$Abs (right). (e) Sex variables in different TNM stages of cancer patients.

Supplementary 3. Figure S3: ROC curve analysis of immune cells and cytokines between metastatic and nonmetastatic patients.

Supplementary 4. Table S1: stages and differentiation types of cancers.

\section{References}

[1] Coronaviridae Study Group of the International Committee on Taxonomy of Viruses, "The species_severe acute respiratory syndrome-related coronavirus : classifying 2019-nCoV and naming it SARS-CoV-2," Nature Microbiology, vol. 5, no. 4, pp. 536-544, 2020.

[2] N. Taleghani and F. Taghipour, "Diagnosis of COVID-19 for controlling the pandemic: a review of the state-of- the-art," Biosensors \& Bioelectronics, vol. 174, p. 112830, 2021.

[3] J. Stebbing, A. Phelan, I. Griffin et al., "COVID-19: combining antiviral and anti-inflammatory treatments," The Lancet Infectious Diseases, vol. 20, no. 4, pp. 400-402, 2020.

[4] J. N. Gustine and D. Jones, "Immunopathology of hyperinflammation in COVID-19," The American Journal of Pathology, vol. 191, no. 1, pp. 4-17, 2021.

[5] H. Sung, J. Ferlay, R. L. Siegel et al., "Global cancer statistics 2020: GLOBOCAN estimates of incidence and mortality worldwide for 36 cancers in 185 countries," CA: a cancer journal for clinicians, vol. 71, no. 3, pp. 209-249, 2021.

[6] N. M. Iyengar, A. Gucalp, A. J. Dannenberg, and C. A. Hudis, "Obesity and cancer mechanisms: tumor microenvironment and inflammation," Journal of Clinical Oncology, vol. 34, no. 35, pp. 4270-4276, 2016.

[7] B. Ritter and F. R. Greten, "Modulating inflammation for cancer therapy," The Journal of Experimental Medicine, vol. 216, no. 6, pp. 1234-1243, 2019.

[8] F. R. Greten and S. I. Grivennikov, "Inflammation and cancer: triggers, mechanisms, and consequences," Immunity, vol. 51, no. 1, pp. 27-41, 2019.

[9] Y. Tan and F. Tang, "SARS-CoV-2-mediated immune system activation and potential application in immunotherapy," Medicinal Research Reviews, vol. 41, no. 2, pp. 1167-1194, 2021.

[10] G. Dranoff, "Cytokines in cancer pathogenesis and cancer therapy," Nature Reviews. Cancer, vol. 4, no. 1, pp. 11-22, 2004.

[11] E. Terpos, I. Ntanasis-Stathopoulos, I. Elalamy et al., "Hematological findings and complications ofCOVID-19," American Journal of Hematology, vol. 95, no. 7, pp. 834-847, 2020.

[12] Y. Tang, J. Liu, D. Zhang, Z. Xu, J. Ji, and C. Wen, "Cytokine storm in COVID-19: the current evidence and treatment strategies," Frontiers in Immunology, vol. 11, p. 1708, 2020.

[13] B. M. Henry, S. W. Benoit, J. Vikse et al., "The antiinflammatory cytokine response characterized by elevated interleukin-10 is a stronger predictor of severe disease and poor outcomes than the pro-inflammatory cytokine response in coronavirus disease 2019 (COVID-19)," Clinical Chemistry and Laboratory Medicine, vol. 59, no. 3, pp. 599607, 2021.

[14] E. J. Giamarellos-Bourboulis, M. G. Netea, N. Rovina et al., "Complex immune dysregulation in COVID-19 patients with severe respiratory failure," Cell Host \& Microbe, vol. 27, no. 6, pp. 992-1000.e3, 2020.

[15] Y. Jamilloux, T. Henry, A. Belot et al., "Should we stimulate or suppress immune responses in COVID-19? Cytokine and anticytokine interventions," Autoimmunity Reviews, vol. 19, no. 7, p. $102567,2020$.

[16] Q. Li, W. Xu, W. X. Li, C. L. Huang, and L. Chen, “Dynamics of cytokines and lymphocyte subsets associated with the poor prognosis of severe COVID-19," European Review for Medical and Pharmacological Sciences, vol. 24, no. 23, pp. 1253612544, 2020.

[17] H. Wu, H. Zhu, C. Yuan et al., "Clinical and immune features of hospitalized pediatric patients with coronavirus disease 2019 (COVID-19) in Wuhan China," JAMA Network Open, vol. 3, no. 6, article e2010895, 2020.

[18] X. Zeng, G. Liu, Y. Pan, and Y. Li, "Development and validation of immune inflammation-based index for predicting the clinical outcome in patients with nasopharyngeal carcinoma," Journal of Cellular and Molecular Medicine, vol. 24, no. 15, pp. 8326-8349, 2020.

[19] M. E. Shaul and Z. G. Fridlender, "Tumour-associated neutrophils in patients with cancer," Nature Reviews. Clinical Oncology, vol. 16, no. 10, pp. 601-620, 2019.

[20] H. Cho, Y. Seo, K. M. Loke et al., "Cancer-stimulated CAFs enhance monocyte differentiation and protumoral TAM activation via IL6 and GM-CSF secretion," Clinical Cancer Research, vol. 24, no. 21, pp. 5407-5421, 2018. 
[21] J. A. Myers and J. S. Miller, "Exploring the NK cell platform for cancer immunotherapy," Nature Reviews. Clinical Oncology, vol. 18, no. 2, pp. 85-100, 2021.

[22] Y. Toyoshima, H. Kitamura, H. Xiang et al., "IL6 modulates the immune status of the tumor microenvironment to facilitate metastatic colonization of colorectal cancer cells," Cancer Immunology Research, vol. 7, no. 12, pp. 1944-1957, 2019.

[23] M. Saraiva, P. Vieira, and A. O'Garra, "Biology and therapeutic potential of interleukin-10," The Journal of Experimental Medicine, vol. 217, no. 1, 2020.

[24] W. Luo, Y. X. Li, L. J. Jiang, Q. Chen, T. Wang, and D. W. Ye, "Targeting JAK-STAT signaling to control cytokine release syndrome in COVID-19," Trends in Pharmacological Sciences, vol. 41, no. 8, pp. 531-543, 2020.

[25] W. J. Leonard, J. X. Lin, and J. J. O'Shea, "The $\gamma_{\mathrm{c}}$ family of cytokines: basic biology to therapeutic ramifications," Immunity, vol. 50, no. 4, pp. 832-850, 2019.

[26] C. Melenotte, A. Silvin, A. G. Goubet et al., "Immune responses during COVID-19 infection," Oncoimmunology, vol. 9, no. 1, p. 1807836, 2020.

[27] R. Karki, B. R. Sharma, S. Tuladhar et al., "Synergism of TNF- $\alpha$ and IFN- $\gamma$ triggers inflammatory cell death, tissue damage, and mortality in SARS-CoV-2 infection and cytokine shock syndromes," Cell, vol. 184, no. 1, pp. 149-168.e17, 2021. 